\title{
Economic Implications of Marine Oil Spill to Nigeria: A Case for Improvement in Coastal Pipeline Management and Surveillance Practices
}

\author{
Nwokedi Theophilus Chinonyerem ${ }^{1}$, Moses Ntor-Ue ${ }^{2}$, Ibe Callistus Chukwudi ${ }^{3}$, \\ Onyemechi Chinedum ${ }^{1}$ \\ ${ }^{1}$ Department of Maritime Management Technology, Federal University of Technology, Owerri, Nigeria \\ ${ }^{2}$ Department of Civil Engineering, Rivers State Polytechnic, Bori, Nigeria \\ ${ }^{3}$ Department of Transport Management Technology, Federal University of Technology, Owerri, Nigeria
}

\section{Email address:}

nwokeditc@gmail.com (N. T. Chinonyerem), mosaic4love@gmail.com (M. Ntor-Ue), callistusibe@yahoo.com (I. C. Chukwudi), c_onyemechi@yahoo.com (O.Chinedum).

\section{To cite this article:}

Nwokedi Theophilus Chinonyerem, Moses Ntor-Ue, Ibe Callistus Chukwudi, Onyemechi Chinedum. Economic Implications of Marine Oil Spill to Nigeria: A Case for Improvement in Coastal Pipeline Management and Surveillance Practices. International Journal of Economy, Energy and Environment. Vol. 2, No. 3, 2017, pp. 40-47. doi: 10.11648/j.ijeee.20170203.12

Received: April 10, 2017; Accepted: April 26, 2017; Published: July 14, 2017

\begin{abstract}
Article 56 section 1 sub-section b(iii) of the United Nations Convention on Laws of the sea (UNCLOS), among other things identifies protection and preservation of the marine environment as a key role which coastal states must perform. While UNCLOS gave sovereign rights of ownership of certain zones in the oceans to coastal states, to fulfill their sociopolitical and economic interests in the use of the oceans and its resources, it also provides that it is the undisputable duty of coastal states to manage their claimed portions of the ocean/marine environment and more importantly, protect the environment from pollution, particularly, pollution from oil and gas $(\mathrm{O} \& \mathrm{G})$ resources. The total quality management approach to safety management views safety progammes and policy implementations as investments, and emphasizes that such investments must be able to yield economic returns among others. The aim of the study therefore is to determine the economic implications of coastal oil spill induced losses to the Nigerian economy in order to estimate the economic impacts that coastal management programmes of agencies has had. The study adopted the natural resources damage assessment model, using data collected from the Nigerian National Petroleum Corporation (NNPC), the Organization of Petroleum Exporting Country (OPEC) and National Bureau for Statistics (NBS), to determine the oil spill induced revenue losses to Nigeria from 1984 to 2012. It was found among other things that within the period covered in the study, $1984-2012$, the Nigerian economy lost estimated 3,928,260,196 naira revenue due to oil spill. This amount is not inclusive of remediation cost, third party costs and impact on the environment. Proactive use of technology for coastal oil pipeline and drilling platform surveillance was recommended.
\end{abstract}

Keywords: Implications, Marine-Oil-Spill, Coastal-Pipeline, Management-Practices

\section{Introduction}

The marine environment comprising the rivers, the oceans and their seas, and the adjacent coastlines, over the years has remained a very rich economic zone, supplying the global economy with varied forms of marine resources; ranging from crude oil and gas and other forms of ocean energy resources, diamond, gold, fisheries, marine biotechnology, marine tourism, to use of the seas as means of transportation.
The socio-economic and political importance of the oceans was realized very early in the history of human development, by both coastal and hinterland states. Thus there existed a serious effort by most coastal states to optimized their socioeconomic and political interest and grip on the seas, with regards to ownership and use of the oceans and her resources, but with little or no attention given to conservation and safety 
of the oceans and their resources from unhealthy practices that cause pollution as well as cause conflict of ocean ownership and management [1].

Reference [2] brought a system of ocean zonation which gave sovereign rights of ownership to coastal states over their territorial seas; which it defines as a distance not exceeding 12 nautical miles, measured from the baselines determined in accordance with the convention, the contagious zone; which it defines as a zone not extending beyond 24 nautical miles from the baseline from which the breath of the territorial sea is measured, necessary for the state to exercise, prevent infringement of its customs, fiscal, immigration or sanitary (pollution) laws and regulations within its territory and territorial seas, as well as punish infringement of the above laws; and the exclusive economic zone (EEZ) defined as a zone beyond and adjacent to the territorial sea but shall not extend beyond 200 nautical miles from the baselines from which the breath of the territorial sea is determined [2]. While the territorial sea, the contagious zone and the EEZ, the continental shelf, the internal waters remain under the sovereign ownership of the coastal states, the "High Seas" (HS) are open to all states, thus, the term "freedom of the high seas". Detailing the duties of the coastal states in Article 56, UNCLOS, among other things in Articles $56 \mathrm{1b}$ (iii) identified protection and preservation of the marine environment as a key role which coastal states must perform. The implication is that while it gave sovereign right of ownership of certain zones in the oceans to coastal states to fulfill their socio-political and economic interests in the use of the oceans and its resources, it also provided that it is the undisputable duty of coastal states to manage their claimed portions of the marine environment and more importantly, protect the environment from pollution, particularly, pollution from oil and gas (O\&G) resources [2].

In Nigeria, agencies have been established at different points in time to handle issues relating to marine environmental pollution, particularly pollution from oil spill. However, a critical evaluation of oil spill issues today shows that the coastline of Nigeria, specifically the Niger Delta area is one of the most polluted and damaged marine ecosystem of the world, occasioned by incessant oil spill from pipelines and drilling platforms [3]. There seems to be lack of concern to the environmental impact of the incessant oil spill by the government and multinational oil companies. It is equally unclear why the revenue losses occasioned by the incessant oil spill seem unimportant to Government, even in the face of serious high level unemployment, low income and poverty challenges among the populace.

In an attempt to x-ray the subject matter of oil spill, reference [4] defines oil spill as the release of liquid petroleum hydrocarbon into the environment accidentally or in the course of operation. It is termed marine oil spillage when the oil pollution is released into the marine environment which consists of the oceans, seas, rivers, lakes, and the adjacent coastal areas and wetland which form an integral network that is essential component of the global productive capital base and positive asset for sustainable development. Oil spill occurs in form of operational and accidental discharges of crude oil and petroleum products from oil transporting marine tankers, offshore drilling platforms, oil wells, oil pipeline transport systems, other shipping activities etc [5]. Statistics indicates that above $70 \%$ of oil spill incidences in Nigeria are pipeline based [6]. The International Maritime Organization views oil pollution in the marine environment as a grave offence which must be seriously dealt with if the marine environment must be protected; thus, the emphasis on the implementation of the provisions of the International regulation for the prevention of marine pollution from ships (MARPOL, 73/78) [7]. Reference [8] notes that the proactiveness of the International Maritime Organization (IMO) in issuing international instruments regulating operational and accidental oil discharges, including the provision of liability and compensation regimes and schemes for oil spill induced economic losses and environmental impacts. Coastal states too, have developed at different points in their existence differing local regulatory instruments and agencies to deal with the menace of oil spill. For example, the Nigeria, Oil Spill Detection and Response Agency (NOSDRA) responds to oil spill issues in Nigeria, the Nigeria Maritime Administration and Safety Agency (NIMASA) Act of 2007 part $\mathrm{X}$ also made provision for the maritime administration body to regulate pollution of the marine environment in Nigeria. It is however viewed, given the frequency and trend of oil spillage in the Nigeria coastal environment, that these agencies have not been proactive in the management of pipeline and drilling platform oil spill incidences in Nigeria. A poor surveillance and responsive management approach to oil spill in the coastline and offshore Nigeria will only continue to aggravate the risks posed by it. For example, the National Bureau for Statistics (NBS) report as reviewed by reference [9] indicate a total occurrence of 6,817 oil spill incidents in Nigeria, between 1976 to 2001, with a total loss of about three million barrels of oil of which $70 \%$ or more remain unrecovered even after remediation activities. The report further indicates that $69 \%$ of these oil spills occurred offshore, $25 \%$ was in swamps, with $6 \%$ on land. Similarly, reference [10] places the volume of crude petroleum jettisoned into the environment yearly at 2,300 cubic meters.

Valuation of the economic/revenue losses occasioned by the wastages at this point is needful, comparison of losses with investment in environmental protection and oil spill control programmes is equally necessary in order to understand the performance level of the agencies in terms of economic contribution. Certainly, wastages and damages of productive capital resources cannot guarantee economic growth, development, employment, and improvement in living standard of the working population. It is equally a sure way, never to attain/achieve the sustainable development goals which are a priority to the nation.

Reference [11] asserts that the major indicators of the 
scale of a country's economy are the Gross Domestic Product (GDP) and Gross National Product (GNP). While the GDP defines the value of the total final output of all goods and services produced in a single year, within the country's boundaries, GNP is GDP plus incomes received by residents from abroad minus incomes claimed by nonresidents [11]. Since a nation's output in terms of GDP depends on level of available means of production or productive resources which includes physical capital, human capital and natural capital (natural resources). The productiveness therefore with which nations engages their productive resources (physical capital, human capital and natural capital) are the widely acceptable indicator of economic development [11]. A wastage and poor use of either or all of the production means could undermine the economic objectives, growth and sustainability of the economic fortunes of the state. This is why optimization and prudence must be achieved in drilling, transportation, storage and use of crude oil and gas resources as a core productive capital of the Nigerian economy. The preponderance and recurrence of oil spill amounts to destructive wastages of the natural resources as a capital base of the Nigerian economy, even in the face of high unemployment rate, poor education, low income, poor technology assimilation penetration rate and lastly, economic recession. Optimality achieved in oil drilling and production, transportation and use by limiting oil spill losses could be used to improve human and physical capital to sustain growth and achieve economic development. Revenue saving achieved from reduction in oil spill induced losses can equally be expended in improving public expenditure in the different areas of need [12].

Though developmental goals vary from one state to another, the United Nations emphasizes "human development measured by life expectancy, adult literacy and access to education at all three levels, as well as people's average income, which is a necessary condition for their freedom of choice [11]. Proactive and strategic management of the marine environment coupled with routine surveillance of drilling platforms and pipeline oil transport systems in use for oil production and transportation in Nigeria Coastal area is needed to limit oil spill induced revenue losses, to improve finances available for public expenditure in the different areas of human development needs [13]. Figure 1 below presents a clearer understanding of the relationship between human development needs, economic growth and government revenue and /or expenditure.

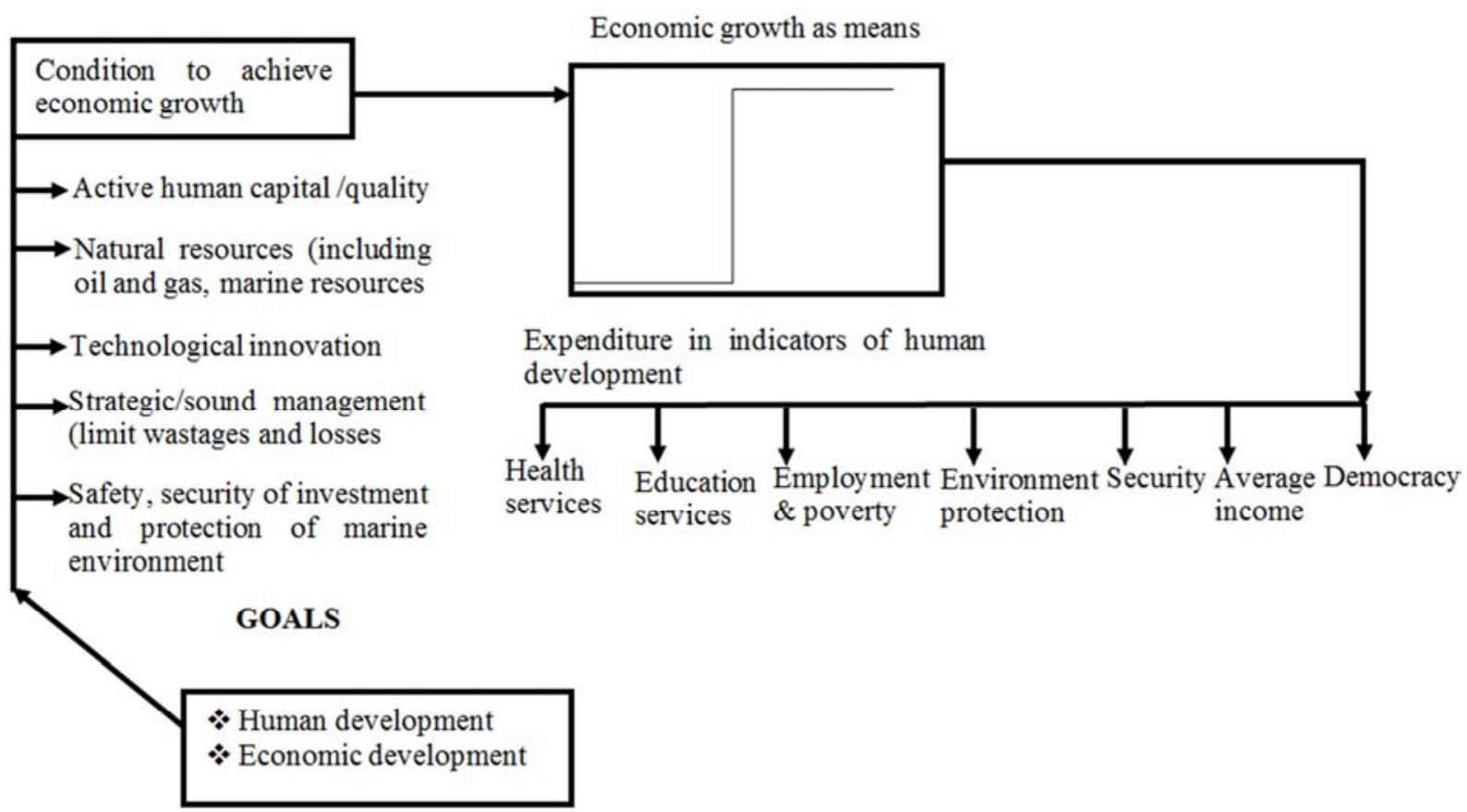

Sources: Modified by author based on UNHDR report.

Figure 1. Different areas of human development needs and relationship with expenditure and economic growth.

As afore mentioned, the reduction of oil spill losses in the short-term will bring about revenue saving to improve public expenditure. The effect when public expenditure is improved is economic and human development, while the long run effect following sustained reduction in oil spill losses is sustainable development whose objectives according to United Nations World Commission on Environment and Development as illustrated in figure 2 below covering three key objectives namely: economic objectives, social objectives, environmental objectives. 
Sustainable Development Objectives

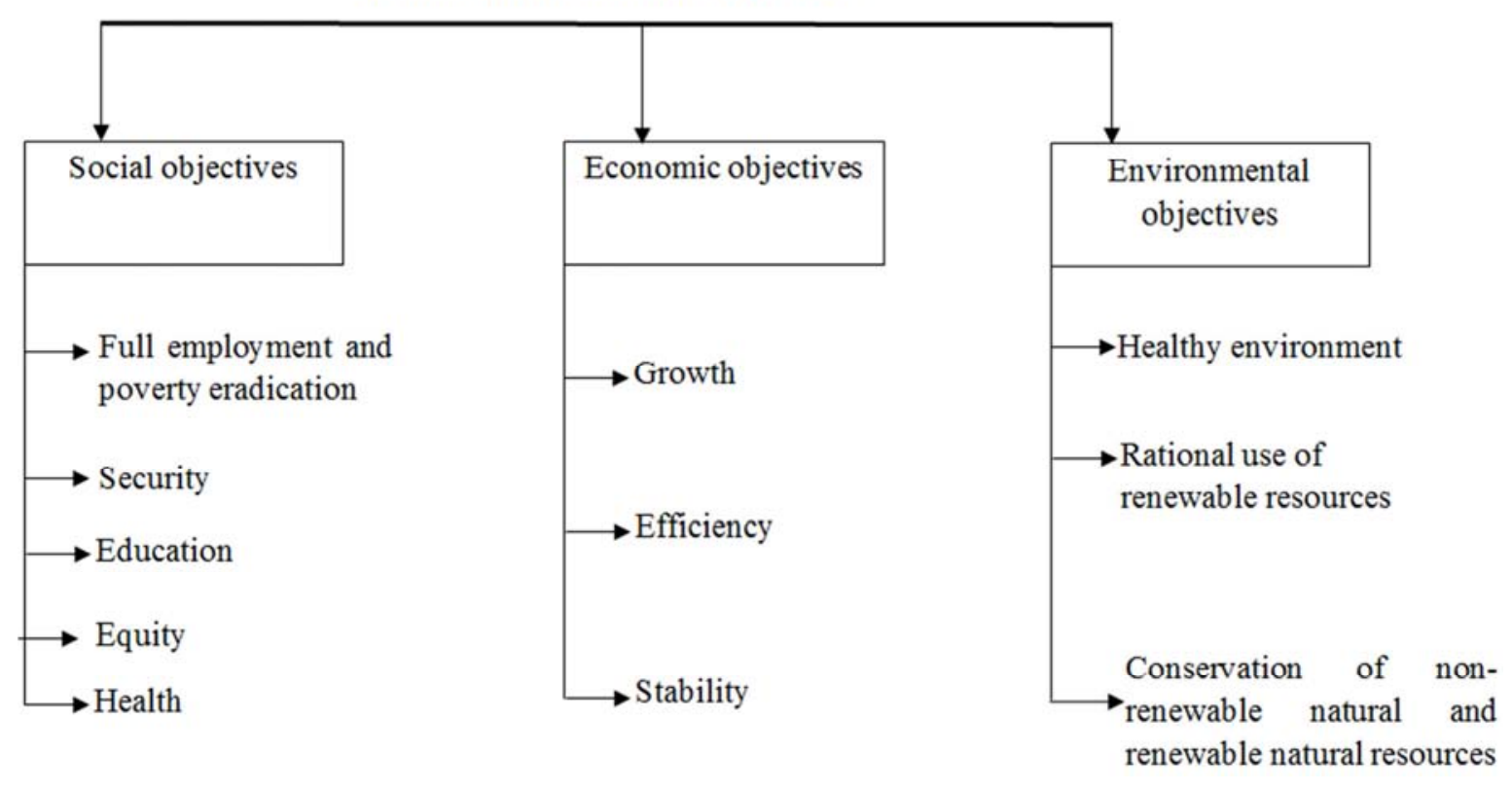

Source: Author preparation.

Figure 2. Objectives to be achieved improved and sustained expenditure in areas of human development needs following sustained reduction or elimination of oil spill induced losses in Nigeria.

\subsection{Objectives of the Study}

The aim of the study to determine the economic risks of marine oil spills to Nigeria. The specific objectives include:

(1) To determine the volume/quantity of oil spill in the Nigerian coastal environment between 1984 and 2012.

(2) To determine the financial value of oil spill losses as direct economic implication of oil spillage to Nigeria.

(3) To determine rate of crude oil loss in barrels per spill incidence in Nigeria within the period covered in the study.

(4) To determine the rate of oil induced revenue losses per annum within the period.

(5) To determine the rate of revenue loss per oil spill incidence in Nigeria within the period

(6) To recommend platform and pipeline improved management and surveillance practices to curtail future oil spill losses.

\subsection{Research Questions}

1) What is the average quantity of crude oil resources spilt in the Nigerian coastal environment within the period covered in the study?

2) What is the economic value of oil spill induced revenue losses to Nigeria within the period covered in the study?

3) What quantum of oil was spilt per incidence within the period covered in the study?

4) What is the rate of oil spill induced revenue losses per annum within the period covered in the study

5) What is the rate of revenue loss per spill incidence?

\section{Brief Review of Literature}

Reference [3] asserts that with the commencement of commercial oil production in Nigeria in 1958, majority of the oil spill incidences occurred in the Niger Delta Coast of Gulf of Guinea. Extensive oil pipeline transport system which transports crude oil and oil products to and from the major refineries in Port-Harcourt, Warri and Kaduna; increases the frequency and probability of the occurrence of oil spill in conjunction with over 1300 oil wells in about 158 oil fields [14], [15]. Most of the oil spill incidences according to reference [16] are attributable to accidental discharge, others are operational discharge. It has equally be proved by reference [16] that illegal oil trading in the Niger Delta also contributes to oil spill leading, to economic losses and pollution of the Nigerian marine environment. Apart from the economic implications of oil spill, which is the central focus of this study, severe environmental damages, loss of mangrove forest, depletion of fish population, contamination of domestic and industrial sources of water, prevalence and promotion of spill-induced diseases and ill health, among others, are key observable impacts of oil spill [13], [17], [18], [12]. Reference [19] in a study on the assessment of economic impact of oil spill losses in the United States of American Marine Environment based on the theory of natural resources damage assessment estimated the cost of oil cost between 1990 to 1994 at 59,096,136 USD. This is exclusive of other costs which [19] identified to included emergency response and remediation (clean up) costs, third party costs, fines and penalties for oil spill, litigation expenses for oil spill and other environmental costs. The above costs may however be covered by insurance and other compensation 
schemes [20]. Since the economy is currently faced with economic recession and low government finances, limiting oil spill induced wastages is important at this time, to salvage the economy from the myriads of economic challenges.

\section{Methodology}

The study adopted an analytical approach to estimate the oil spill revenue losses to Nigeria and determine the sum total of barrels lost and the related revenue lost from 1984 to 2012 . Statistical data on oil spill frequency and quantity of oil (in barrels) spilt between 1984 and 2012 were obtained from the National Bureau for Statistics (NBS) and Petroleum Resource Department of the Shell Petroleum Development Corporation (SPDC). The per barrel prices (OPEC) of oil in the international market per year from $1984-2012$ were obtained from the annual statistical publication of the Organization of Petroleum Exporting Countries (OPEC). The National Resources Damage Assessment Method (NRDAM) used by references [19] and [20] was used to estimate the oil spill economic/revenue losses in each of the years covered in the study. The NRDAM determines the quantitative relationship between oil spill quantity and price per year and uses this relationship between quantity and price to estimate the revenue losses per annum. For example, given that the oil spill induced revenue losses $\left(\mathrm{R}_{\mathrm{L}}\right)$ is dependent on the product of oil spill quantity $\left(\mathrm{Q}_{\mathrm{S}}\right)$ and per barrel price $\left(\mathrm{P}_{\mathrm{o}}\right)$.

We can express the above revenue losses as a function of quantity spilt and per barrel prices such that:

$$
\mathrm{R}_{\mathrm{L}}=\mathrm{F}\left(\mathrm{Q}_{\mathrm{S}}, \mathrm{P}_{\mathrm{o}}\right)
$$

Thus, for each year,

$$
\mathrm{R}_{\mathrm{L}}=\mathrm{Q}_{\mathrm{S}} \mathrm{P}_{\mathrm{o}}
$$

Thus, a change in $\mathrm{R}_{\mathrm{L}}$ (oil spill revenue loss) over time will occur with changes in $\mathrm{Q}_{\mathrm{S}}$ and $\mathrm{P}_{\mathrm{o}}$.

Thus,

$$
\frac{\partial R_{L}}{\partial t}=P_{O}(t) \cdot \frac{\partial Q_{S}(t)}{\partial t}+Q_{S}(t) \cdot \frac{\partial P_{O}(t)}{\partial t}
$$

The above equation serves to estimate revenue losses when changes in oil prices occur at the long-run

It is equally noted that a relationship exist between oil spill quantity per annum and annual frequency and/or sum of spill occurrences per annum. Since the state cannot all alone influence positive changes in international oil prices, $P_{o}$ is an uncontrollable variable to the State; thus a sustained change (reduction) in $R_{L}$ will occur/be achieved with a sustained limitation/reduction in frequency of occurrence $\left(F_{S}\right)$ and spill quantity $\left(Q_{S}\right)$. The short-run revenue loss when $\mathrm{P}_{0}$ is unchanged (constant at the short-run) is thus given as:

$$
\delta R_{L}=P_{0}\left(\delta Q_{s}\right)
$$

Furthermore, present values (PV) of oil spill economic losses $R_{L}$ in each of the past $n$ years can be determined by applying the appropriate/prevailing interest rates (r) as compound amount factor to compound $R_{L}$ to present values $(P V)$. Thus,

$$
R_{L}(1+r)^{n}
$$

gives the $P V$ of output losses due to oil spill.

The study used;

$$
R_{L}=Q_{S} P_{o}
$$

and

$$
\frac{\partial R_{L}}{\partial t}=P_{O}(t) \cdot \frac{\partial Q_{S}(t)}{\partial t}+Q_{S}(t) \cdot \frac{\partial P_{O}(t)}{\partial t}
$$

to determine the economic value of output losses due to the oil spill in Nigeria. Subsequently, simple arithmetic averages were used to further analyze the data in order to draw inferences.

Note: $R_{L}=$ oil spill economic loss (revenue loss due to oil spilt induced output losses).

$Q_{S}=$ spill quantity per year

$Q_{t}=$ total quantity of spill between $1984-2012$

$P_{o}=$ per barrel price of oil each year.

$(1+r)^{n}=$ Compound amount factor

$P V=$ present value of oil spill losses

$n=$ No of years covered

$r=$ Interest rate

$\frac{\delta R L}{\delta t}=$ Change in oil spill revenue loss with change in time.

$\frac{\delta Q_{S}}{\delta t}=$ Change in spill quantity with change in time.

$\mathrm{F}_{\mathrm{s}}=$ Spill frequency/number of occurrence per year, $\mathrm{Q}_{\mathrm{st}} / \mathrm{Fst}$ $=$ quantity spilt per incident

$\mathrm{R}_{\mathrm{Lt}}=$ total oil spill revenue losses over the period of the study

$\mathrm{Q}_{\mathrm{st}}=$ total barrels lost within the period, $\mathrm{R}_{\mathrm{Lt}} / \mathrm{F}_{\mathrm{st}-}=$ Total revenue lost per incident

$\mathrm{F}_{\mathrm{st}}=$ total occurrences over the period, $\mathrm{R}_{\mathrm{Lt}} / \mathrm{Q}_{\mathrm{st}}=$ revenue loss per quantity spilt

$\mathrm{R}_{\mathrm{Lt}} / \mathrm{n}=$ Revenue loss per annum, $\mathrm{Q}_{\mathrm{st}} / \mathrm{n}=$ average quantity spilt per annum.

\section{Limitations of the Study}

The study is limited to the estimation of the economic value of output losses due to oil spillage in Nigeria between 1984 and 2012. Though time constituted a serious limitation to the timely collection of data needed for the research; such constraint was however overcame by strategic mobilization of financial resources to download and print soft copies of various editions of statistical bulletins of the organization to which data was sourced. It is however important to indicate the statistical data used in this work are sourced from the online versions of statistical publication of the Nigerian national petroleum Corporation (NNPC), National Bureau for Statistics (NBS) and organization of Petroleum exporting Countries (OPEC). The extent of accuracy of the result and findings here is therefore affected to extent and accuracy of the data sourced from these agencies and used in the work. 


\section{Presentation of Results and Discussion of Findings}

Table 1. Result of analysis obtained by use of the Human Resource Damage Assessment Model.

\begin{tabular}{|c|c|c|c|c|c|}
\hline S/No & Year & $\mathbf{F}_{\mathbf{S}}$ & $\mathbf{Q}_{\mathrm{s}}$ & $\mathbf{P}_{0}$ & $\mathbf{R}_{\mathbf{L}}$ \\
\hline 1 & 1984 & 151 & $40,209.00$ & 23.09 & $928,425.81$ \\
\hline 2 & 1985 & 187 & $11,876.00$ & 26.91 & $319,583.16$ \\
\hline 3 & 1986 & 155 & $12,905.00$ & 47.94 & $618,665.7$ \\
\hline 4 & 1987 & 129 & $31,866.00$ & 74.37 & $2,369,874.42$ \\
\hline 5 & 1988 & 208 & 9,172 & 74.90 & $686,982.80$ \\
\hline 6 & 1989 & 195 & $7,682.16$ & 100.39 & $765,790.98$ \\
\hline 7 & 1990 & 160 & $14,940.82$ & 216.02 & $3,227,343.12$ \\
\hline 9 & 1992 & 378 & $51,187.96$ & 393.21 & $20.128,027.26$ \\
\hline 10 & 1993 & 4128 & $9,752.22$ & 362.09 & $3,531,121.34$ \\
\hline 11 & 1994 & 515 & $30,282,20$ & 354.55 & $10,736,650.91$ \\
\hline 12 & 1995 & 417 & $63,677.17$ & 1461.6 & $93,070,551.67$ \\
\hline 13 & 1996 & 430 & $46,333.12$ & 1706.4 & $79,096,963.97$ \\
\hline 14 & 1997 & 339 & $81,727.85$ & 1638 & $133,870,218.3$ \\
\hline 15 & 1998 & 339 & $99,885.35$ & 1177.6 & $117,624,988.2$ \\
\hline 17 & 2000 & 637 & $64,071.91$ & 2612.6 & $219,646,272.1$ \\
\hline 18 & 2001 & 412 & $120,617.16$ & 2731.8 & $330,420,719.9$ \\
\hline 19 & 2002 & 446 & $241,617.55$ & 3060.7 & $739,519,998.4$ \\
\hline 20 & 2003 & 609 & 35284.43 & 3739.1 & $132,658,871.5$ \\
\hline 21 & 2004 & 543 & $17,104.20$ & 5147.1 & $88,235,998.4$ \\
\hline 22 & 2005 & 496 & $10,734.6$ & 7420.3 & $79,653,878.18$ \\
\hline 23 & 2006 & 540 & $19,022.23$ & 8454.6 & $160.823,654.8$ \\
\hline 24 & 2007 & 462 & $30,175.00$ & 11346.6 & $342,383,655$ \\
\hline 25 & 2008 & 481 & 21,567 & 6838.2 & $147,482,399.8$ \\
\hline 26 & 2009 & n.a & $17,257.20$ & 12343.7 & $213,017,699.6$ \\
\hline 27 & 2010 & - & $32,276.9$ & 13024.0 & $420,373,954.9$ \\
\hline 28 & 2011 & - & $13,245.00$ & 15522.8 & $203,494,926$ \\
\hline 29 & 2012 & - & $23,430.00$ & $17,136.1$ & $230,137,825.00$ \\
\hline$Q_{S t}, R_{L t}, F_{s t}=$ & & 1184 & $1,301,397.2$ & - & $3,928,260,196.00$ \\
\hline
\end{tabular}

Sources: $\mathrm{R}_{\mathrm{L}}=$ authors calculations based on data collected.

$\mathrm{P}_{\mathrm{o}}=$ Sourced from various editions of Central Bank of Nigeria statistical bulletin and OPEC.

$\mathrm{F}_{\mathrm{s}}$ and $\mathrm{Q}_{\mathrm{S}}=$ Sourced for NBC and NNPC reports

Table 2. Table showing statistical deductions based on table1.

\begin{tabular}{llllllll}
\hline $\mathbf{Q}_{\mathrm{St}}$ & $\mathbf{F}_{\mathbf{S t}}$ & $\mathbf{R}_{\mathbf{L t}}$ & $\mathbf{R}_{\mathbf{L t}} / \mathbf{F}_{\mathbf{S t}}$ & $\mathbf{Q}_{\mathbf{S t}} / \mathbf{F}_{\mathbf{S t}}$ & $\mathbf{R}_{\mathbf{L t}} / \mathbf{Q}_{\mathbf{S t}}$ & $\mathbf{R}_{\mathbf{L t} / \mathbf{n}}$ & $\mathbf{F}_{\mathbf{S t}} / \mathbf{n}$ \\
\hline $1,301,397.2$ & 1184 & $3,928,260,196$ & $3,317,787.3$ & 1099.153 & $3,018.49$ & $135,457,248.1$ & 47.36 \\
\hline
\end{tabular}

Source: Authors calculation based on table1.

The result of the analysis as presented in table1 shows nonconsistency in the nature and trend of oil spill occurrences in Nigeria, with rising very sharply from the base year value of 151 in 1984. There is evidence in the very high difference in the number of occurrences in 1984 base year value of 151 and the 2008 value of 481 occurrences. The difference is 330 occurrences. Similarly, the differences in the base year spilt quantity and 2012 spilt quantity is 16,779 barrels, indicating a decline. However, there was no corresponding decline in revenue loss, following a far higher per barrel price in 2012. The economy rather lost higher amount by approximately 229 , 909,400 Nigerian naira in 2012. Obviously, the number of spill occurrence, quantity (barrels) of oil spilled and economic loss of revenue occasioned by spill from 1984 to 2012 as covered in the study has followed no defined pattern. The average oil spill occurrence per annum was 47.36 spill incidences. 44, 875.76 barrels was spilt per annum and 135,457,248.13 naira was lost per annum. Furthermore, table 2 shows that an average of 1099.153 barrels of oil was lost per spill incident while an average of 3,317,787.3 naira was lost per spill incident. The average economic loss per barrel of oil spilt amounts to 3,018.49 per barrel of oil spilt within the period covered by the study. The total quantity of oil lost and total financial value of oil spilt within the period amounts to 1,301,397.2 barrels and $3,928,260,196$ naira in respectively in 1184 incidences. These represent the direct economic implications of oil spill losses, to the Nigerian economy. That brings to question the potency and effectiveness of agencies of government responsible for environmental protection and management.

The implication is that over the years, while the country has shown serious efforts at tapping and managing the exploration and exploitation of oil and gas resources and other socio-political and economic benefits of the coastlines based on the provisions of UNCLOS 1982, it has neglected equally, the provision of the same UNCLOS 1982 to limit pollution and protect the marine environment. The 
government over the years through her agencies responsible for spill control has failed to recognize the level of damage done to the marine ecosystem as to limit the occurrences of oil spill, much so that they have seem to have no knowledge of the revenue losses occasioned by spill. Efforts must be geared towards combating the occurrence of oil spill by government agencies responsible for this, through strategic proactive management and improved pipeline surveillance practices. The use of drones, tero-technology and robotics will help. The tero-technology options offers proactive maintenance management of drilling and pipeline equipments by auto-inspection and maintenance following a lifecycle approach. Thus, aging pipeline and $O \& G$ installation which pose the risk of spill will be observed in advance and replaced near or towards the end of its life span, when such cannot cause spill.

\section{Conclusion}

The findings of the research lay credence to public opinion that the coastal environment and coastal pipelines in Nigeria is being poorly managed. It is important to note that environment protection cum optimization of economic benefits is the key motivator that drives investment in coastal pipeline management. The present system of management has shown abysmal poor performance with as it relates to both. The study however concludes in line to the objectives of the research as follows:

(1) Within the period covered in the study, $1984-2012$ the Nigerian economy lost an estimated 3,928,260,196 naira revenue due to oil spill. This amount is not inclusive of remediation cost, third party costs and impact on the environment.

(2) Total of 1184 oil spill incidences led to the spill of total sum of 1,301,397.2 barrels of oil over the 29 years period.

(3) An average of 1099.153 barrels was lost per spill incident with an average economic loss of 3,317,787.3 naira per spill incident.

\section{Recommendations}

1) Coastal pipeline and offshore oil installations spill reduction management efforts must be strategically proactive with serious drive to minimize both economic and environmental impacts. The present practice of responsive approach to oil spill management where control efforts are only initiated when an incident is reported old fashioned and must be re-evaluated and updated. Potential sources and causes of risk factors must be proactively detected by means of human aided technology surveillance system and nipped in the bud.

2) The use of technology in surveillance of the coastline and offshore pipelines and oil installations is recommended. For example, the use of drones, robotics and terro-technology in pipeline and ship-fault surveillance (inspection) reduces chances of spill. While the use of drones may prove very costly, the use of terrotechnology offers a lifecycle approach to proactive autoinspection and maintenance management of offshore equipments and pipeline installations. Thus using the system, faulty equipments and aging installations can be detected and corrected or replaced before they cause and or increase the risk of oil spill.

3) Apart from the use of technology, coastal pipelines can be policed using human capital. Employing the right level of manpower with requisite skill determined through a qualitative process of needs assessment, can be employed and used to police the coastal pipelines. This will eliminate or reduce deliberate destruction of pipelines and oil installation by oil thieves operating in the coastal zones of Nigeria. It is no longer fashionable to wait in the office to receive an oil spill accident report from third parties before rushing to the field to respond, as has been the practice over the years.

4) Lastly, there is urgent need to repeal the various Acts (Laws) that setup the different maritime and coastal management agencies of government such as the Nigerian Maritime Administration and Safety Agency Act of 2007 and the National Oil Spill Detection and Response Agency and the (NOSDREA) Act. Such repeal should note the total absence of any clause mandating professional annual evaluation of the performance of these agencies by an independent board with regards to oil spill detection and control and general marine environmental protection and safety. Thus, new clauses should be inserted, mandating an annual performance audit of the agencies with regards to marine environmental pollution control. However, such an audit or appraisal should not be limited to evaluating how they have responded to oil spill incidences and general marine environmental pollution, but extended to evaluate the economic impacts of their proactiveness in management of oil spill and pollution issues in the marine environment on economic growth, economic development sustainable development.

\section{Acknowledgements}

I sincerely acknowledge NBS, NNPC and OPEC for diligent releases of their annual statistical bulletins and reports used in this work. My appreciation also goes to the academic staff of Department of Maritime Management Technology, Federal University of Technology, Owerri, Nigeria for their support and inspiration.

\section{References}

[1] Heid, T., Evelin, P., Tea, N., Aljona, K., Sulev, N., Mikolaj, C. and Nick, H. (2016) Valuing the benefits of improved marine environmental quality under multiple stressors. Sciences of the Environment 551 - 556:367-375. 
[2] The United Nations Convention on Law of the Seas (UNCLOS, 1982). United Nations, London.

[3] Adati, A. K. (2012) Oil exploration and spillage in the Niger Delta of Nigeria. Journal of Civil and Environmental Research Vol. 2(3):38-52.

[4] Adelana, S. O., Adeosun, T. A., Adesina, A. O. and Ojuronye, M. O. (2011) Environmental pollution and remediation: Challenges and Management of Oil Spill in Nigeria Coastal Areas. American Journal of Science and Industrial Research 10.5251(836)834-845.

[5] Nwokedi, T. C., okoroji, L. I., Nze, I. C. and Ndukwu, I. P. (2014) Oil exploration and production waste management practices: comparative analysis for reduction in hazardous E\&P waste generation in offshore oil platforms in Nigeria. Journal of Environmental and Earth Science Vol. 5 (4): 101 107.

[6] Nigeria National Petroleum Corporation (NNPC, 2013) Annual Statistical Report. Available at www.nnpc.org.ng/ retrieved on 25/07/2016.

[7] International Maritime Organization (IMO, 2011) International shipping facts and figures, information resources on trade, safety, security, environment. Maritime Knowledge Center, London.

[8] Ufia P. (2011) Marine environmental protection and safety. A seminar material at the Nautical Institute for Technology, Rivers State University of Science and Technology, Onne Campus.

[9] Nwokejiegbe, C. E. (2014) An assessment of the impacts of marine pollution by oil spill in Nigeria. B. Tech. Thesis in the Department of Maritime Management Technology, Federal University of Technology, Owerri.

[10] Nigeria National Petroleum Corporation (NNPC, 2011) Annual Statistical Report. Available at www.nnpc.org.ng/ retrieved on 25/07/2016.

[11] Tatyana, P. S. (2004) Beyond economic growth: An introduction to sustainable development. International Bank for Reconciliation (World Bank), Washington.

[12] Emeonyeonu, U. M. (2014) An impact assessment of oil pollution in the Niger Delta Region: A Pygovian tax approach. M.Sc. Thesis in the Department of Maritime Management Technology, Federal University of Technology, Owerri.

[13] Badejo, O. T. and Nwilo, P. C. (2004) Management of oil spill disposal along the Nigeria coastal areas. ISPRS Congress 2004, Istabul, Turkey.

[14] Onuoha, F. C. (2008) Oil pipelines sabotage in Nigeria: Dimensions, actors and implications for national security. African Security Review, Institute for Security Studies 17(3)42-50.

[15] Anifowoze, I. (2008) Health Implications of oil spill in the Niger Delta of Nigeria. A seminar material in the Department of Administration, Nautical Institute for Technology, Onne campus, UST, Port-harcourt, Nigeria.

[16] Elei, G. I. (2014) Illegal oil trading in Nigerian maritime industry and its impacts on the economy. $\mathrm{A} \mathrm{Ph}$. D. Dissertation in the Department of Maritime Management Technology, Federal University of Technology, Owerri.

[17] Uyigue, E., Agho, M. (2007) Copping with climate change and environmental degradation in the Niger Delta of Southern Nigeria. Community Research Development Center, Nigeria (CREDC).

[18] Micheal, F. and Hui, W. (2015) Compensating victims of a European deepwater horizon accident: OPOL revisited. Marine policy 62:25 - 36 .

[19] Ando, A. W., Madhu, K., Amy, W., Suzanne, V. (2004). Natural resources damage assessment methods and cases. WMRC's Research Report Series. Available at http//:wrurc.uivc.edu/retrieved:26/05/2016.

[20] Grey, D., Rob, F. (1997) The economic impact of accident on the marine industry. Prepared for the U.S. coast guard, standards evaluation and development division, Washington. 